\title{
Artelogie
}

artelogie Recherche sur les arts, le patrimoine et la littérature de I'Amérique latine

$11 \mid 2017$

Délocalités, translocalités et activisme dans l'art électronique et biomédiale latino-américain

\section{José Alejandro Restrepo. Tres décadas de creación con el arte y la tecnología.}

Jorge La Ferla

\section{(2) OpenEdition \\ Journals}

Edición electrónica

URL: http://journals.openedition.org/artelogie/1531

DOI: 10.4000/artelogie.1531

ISSN: 2115-6395

Editor

Association ESCAL

Referencia electrónica

Jorge La Ferla, « José Alejandro Restrepo. Tres décadas de creación con el arte y la tecnología. », Artelogie [En línea], 11 | 2017, Publicado el 01 diciembre 2017, consultado el 19 abril 2019. URL : http:// journals.openedition.org/artelogie/1531; DOI : 10.4000/artelogie.1531

Este documento fue generado automáticamente el 19 abril 2019.

Association ESCAL 


\title{
José Alejandro Restrepo. Tres décadas de creación con el arte y la tecnología.
}

\author{
Jorge La Ferla
}

\section{La obra del artista colombiano José Alejandro Restrepo}

1 La obra del artista colombiano José Alejandro Restrepo reviste un modelo significativo para considerar un panorama histórico de las artes tecnológicas. Su variada formación e interés las artes visuales y escénicas, la instalación, la performance y la producción editorial permiten trazar un panorama que dialoga con diversos recorridos de las artes mediáticas en América Latina. En el reciente Festival Internacional de la Imagen de Manizales, donde tuvo lugar ISEA 2017, se propusieron diversos trayectos para una visión comprensiva e histórica del arte, la ciencia y la tecnología en el continente. El video arte está en el origen de la historia de las artes electrónicas en el continente. Y se pueden considerar vínculos operativos con las artes performáticas, el grabado, el diseño editorial y la fotografía que se han combinado con las prácticas electrónicas como propuestas de revisión de una historia que se continuó con el procesamiento matemático de datos y la programación, para definir una entelequia que abarca la imagen digital en toda su amplitud hasta para llegar a un estadio de post mediático.

2 La obra de José Alejandro Restrepo comenzó a circular en América del Sur a través deI Primer Festival Francolatino de Videoarte, 1992, en el que participó con su obra monocanal Serie 3. Al año siguiente, la selección de videos colombianos para la segunda edición del festival, fue realizada por el mismo Restrepo, en este caso cumpliendo el rol de un atento curador. Así es como fuimos siguiendo su obra, sus muestras, su trabajo académico y editorial, así como los variados discursos alrededor de su obra a lo largo de estas décadas en que se ha convertido en una figura central del arte contemporáneo. 
3 En ese tiempo era notable la profusión de realizadores de video con una obra incipiente e, independiente por donde se la mirara, de profundas innovaciones en la vertiente documental, el uso de archivos y la intervención expresiva en la materialidad del soporte como resultado de una experimentación inclaudicable. Si bien era un país europeo el que impulsaba estos festivales alrededor del video $\operatorname{arte}^{1}$, se promovía el encuentro e intercambio entre autores de América Latina. La circulación de artistas y obras entre algunos países se ampliaría a partir de entonces, con la particular relevancia del video argentino, brasileño, chileno y colombiano. Han pasado más de veinticinco años, el video ya no se destaca como un soporte autónomo, el mercado ya no ofrece soportes analógicos y la tecnología audiovisual se ha vuelto numérica operando a través de programas informáticos ${ }^{2}$. El estatuto del videoarte y el cine experimental, según se pudo haber formulado en aquel momento del siglo $\mathrm{XX}$, ha variado y una parte de aquellos destacados videoartistas han cejado en su producción por diferentes motivos ${ }^{3}$, siendo escasos los que se mantienen en la brecha ${ }^{4}$ en América Latina. Así es como la historia de las artes electrónicas en el continente tiene a Restrepo como protagonista, en tanto modelo de autor en el que convergen la imagen electrónica, la instalación, el performance, la enseñanza, las producción editorial, conformando particularmente, en su combinatorias y distintas versiones, un partido conceptual y una sistemática proyectual que anteceden y exceden la temporalidad de sus exhibiciones.

4 Aquellos recordados textos curatoriales de Restrepo, "Video-Apuntes" (Restrepo, 1993), proponían recorridos por cuestiones que conforman la representación y el estatuto de la imagen, la comunicación y los valores sensoriales humanos, hasta llegar al mismo video, algo que mantiene vigente al día de hoy. Restrepo evitaba los lugares comunes vinculados a la producción y circulación del video colombiano, frecuentes en los catálogos de la época, que solían describir las obras y su inserción anecdótica en el contexto nacional ${ }^{5}$. En cambio, el escrito articulaba citas de filósofos, sabios indígenas, textos místicos, y reflexionaba sobre las maneras de poner en escena la memoria, a partir tanto de la historia y del mito oral, como de un pensamiento sobre los medios masivos de comunicación desde el videoarte, la imagen y el sonido ${ }^{6}$. Restrepo proponía en aquel momento incipiente intertextos que se aplicaban a su propia obra, partiendo de referencias históricas, textos filosóficos, relatos originarios americanos, la crítica a las representaciones del poder y las ideologías, y una permanente focalización en el complejo contexto colombiano. Una propedéutica de recorridos admirables que sustentan una puesta en obra y en palabra sistemática para un arte de la retórica que nos llevaría a pensar una verdadera historia del video y las artes contemporáneas ${ }^{7}$. 
Estilita (2012); El caballero de la fé (2012).

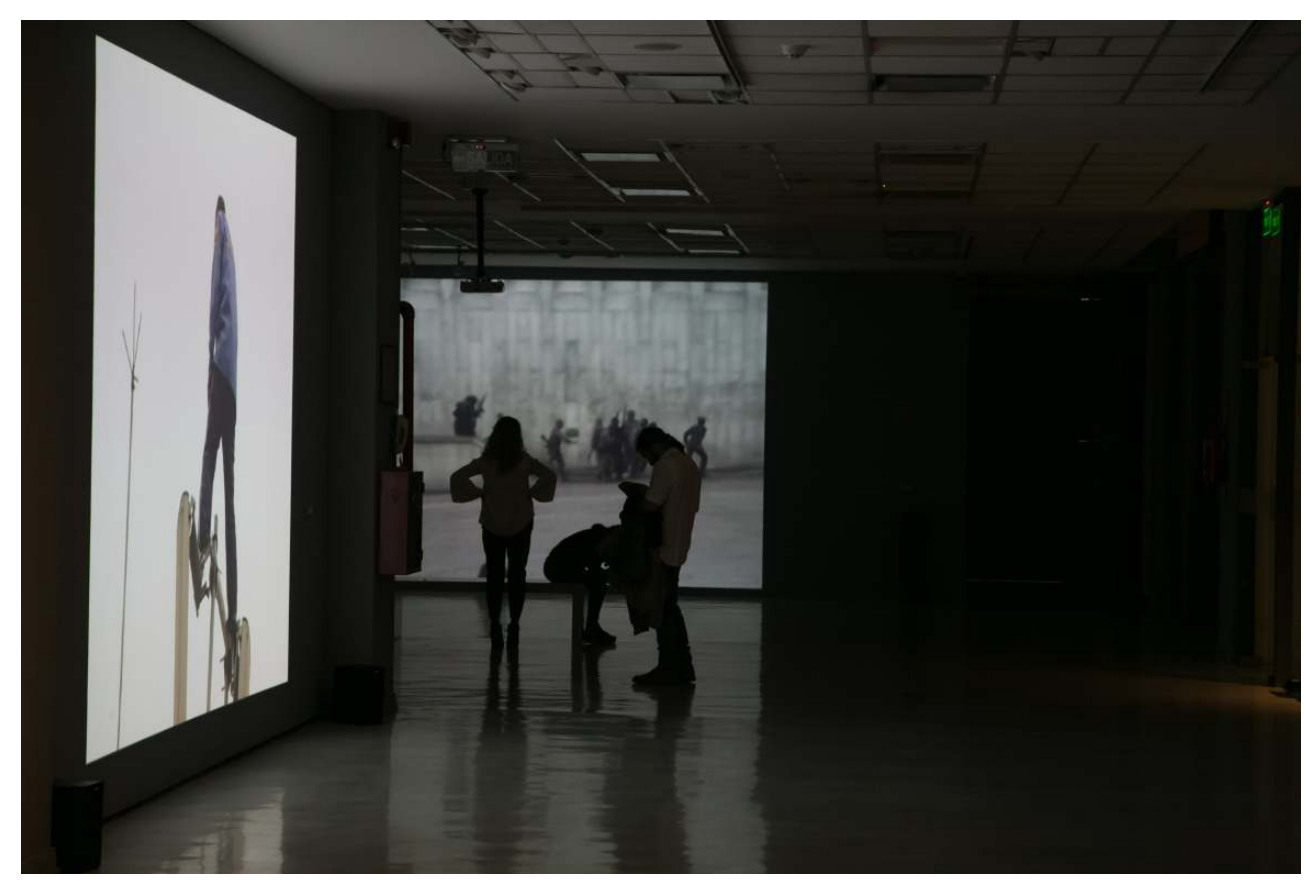

Montaje Religión Catódica, Buenos Aires 2017, Espacio de Arte de la Fundación OSDE.

FOTO ESTUDIO LEDESMA HUEYO

5 Restrepo ha mantenido su producción de video monocanal a lo largo del tiempo, la cual recurre, en parte, a la apropiación de imágenes televisivas cuya manipulación deriva en la creación de otros significados, desvirtuando la ideología del dispositivo de la emisión, ya sea directo o diferido. La antológica serie ICONOMIA-Iconofilia/iconoclastia (2000-2013) marca un punto de inflexión, por su amplitud y desarrollo, en el largo proceso de considerar el flujo televisivo como lugar de observación del valor de la imagen, de su culto y condena, pues replica con énfasis las categorías de idolatría, iconodulia e iconoclasia desde su origen religioso hasta una historia reciente que no puede desentenderse del valor de la imagen en el contexto contemporáneo de Colombia. Tomemos por caso dos obras que continúan con esta saga, pero que se centran en hechos o sucesos puntuales, como es el caso de El Caballero de la Fe (2012), que deriva del espectáculo mediático de los trágicos sucesos de 1985 ocurridos en el Palacio de Justicia de Bogotá, cuando luego haber sido tomado por un grupo guerrillero es recuperado por una acción militar que termina en una masacre indiscriminada. La presencia de la televisión siguiendo los hechos enfrente del ministerio fue parte de un interminable espectáculo en vivo. En medio de la extensa transmisión, una de las cámaras de ponía el foco en un personaje que ensimismado deambulaba por la plaza dando de comer a las palomas mientras seguía el combate en la profundidad de campo y un desencuadre ominoso. Esta elocuente digresión señalaba la acción minimalista de la cámara de televisión que desviaba su observación del frente de batalla, dislocando la impronta efectista del espectáculo transmitido live. Restrepo recupera sagazmente esos breves fragmentos, resignificándolos desde su identificación y captura hasta su (des)montaje. Por su parte, Estilita (2012) presenta otro personaje anónimo del entorno urbano que se mantiene de pie sobre unas antenas de telefonía mientras habla desde su móvil, lanza al aire una nota manuscrita, sostiene el equilibrio. La falta de comunicación amorosa es 
elocuente para el punto de vista de la cámara cuyo plano contrapicado recorta al protagonista en los cielos. Este fragmento televisivo es modificado por el efecto video del ralentí y por la puesta sonora, que proponen otra visión que se aleja de la nota policial. La reformulación de Restrepo presenta al protagonista como un eremita contemporáneo que medita en soledad desde las alturas de la ciudad y cuya observación sobrelleva un particular éxtasis. Esta sistemática de apropiación de fragmentos aislados televisivos es la materia prima que Restrepo reinscribe para construir otro discurso sobre el entorno moderno y que en otros casos remite a un pasado histórico. En Tecnología para gentiles (2014) las habituales ceremonias mediáticas que realizan los mandatarios de la región en sus visitas esporádicas a las comunidades indígenas son comentadas por dichos $\mathrm{y}$ leyendas de la época colonial a partir de sentencias que son inscritas electrónicamente, siempre sobre los archivos de la TV. Las incisiones tipográficas comentan y connotan estas imágenes del presente. Los repertorios de sentencias religiosas sobre los buenos salvajes y los textos televisivos contemporáneos colisionan en un montaje conceptual de la historia que articula la visión de los colonizadores con la demagogia de los políticos en funciones como parte de un mismo discurso discriminatorio sobre el otro. Esta vez, todo el conjunto se presenta en el video como carpetas de repertorios digitales sobre la pantalla de un computador, matriz contemporánea de los registros del pasado, a partir del cual son identificados y procesados. Los ejercicios de lectura del archivo, su desmontaje $^{8}$, y por ende de su reescritura, hacen que este conjunto de obras de video se inserten en una dialéctica de confrontación transhistórica que Restrepo presenta con carácter sistemático en sus escritos y personalmente, cuando asiste y presenta su trabajo. Restrepo suele presentar estas piezas de video que funcionan autónomas dentro del legendario dispositivo de la sala oscura y la pantalla blanca, que lamentablemente muchos festivales de video han venido dejando de lado y que requieren otra percepción a partir del tiempo lineal de proyección para un espectador sentado. Así es como Restrepo se suele sitúar entre el público y la pantalla para referirse a cada obra. El significativo gesto de presentarlas en cuerpo presente se complementa con la proyección y las luces apagadas, intermedios en los que Restrepo se maneja con soltura discursiva y escénica para un ceremonial elocuente en el que expone los procesos de construcción y significación de cada trabajo. Asimismo, esto sucede en sus alocuciones públicas, conferencias y clases, cercanos a una forma de pensamiento, que se asocia a una acción performática, práctica que domina con certeza y convicción. Ya sea cuando las trabaja en sus obras, como cuándo realiza estas alocuciones públicas en que Restrepo se refiere a su propia obra.

6 Las piezas de video también suelen ser parte de una instalación, una muestra o un ejercicio escénico, expansiones que eluden la mera exhibición de los videos en el espacio de la galería o el museo. Ocupar un espacio institucional de arte en un lapso de tiempo es para Restrepo proponer un conjunto de prácticas concentradas en el arte de la instalación, que suele incluir acciones performáticas, variados objetos, serigrafías, grabados, fotografías, piezas editoriales, intervenciones site specific. Tres exhibiciones personales de una larga serie de muestras señalan distintos modelos de muestras personales. Por un lado TransHistorias (2001), con ocho videoinstalaciones ${ }^{9}$ para un conjunto de obras que ofrecían un recorrido emblemático a partir de la dialéctica que confrontaba escritos e imágenes de la historia, relatos y recorridos por regiones de Colombia: el discurso de la ciencia y el racionalismo se confrontaban con el mito indígena, el saber popular y vestigios de narraciones provenientes de diversas partes del país. Son 
lecturas para un relato crítico que cuestiona los aparatos ideológicos del Estado asentados en los manuales escolares, los cantos patrios, los lugares comunes y los medios masivos de comunicación. Estas fricciones hacen de Restrepo un comentador privilegiado que procesa la realidad colombiana y, por extensión, del continente, a través de formas de representación que se concentran en la práctica híbrida de la instalación en el espacio expositivo. El tiempo de cada obra, en su recorrido espacio/temporal, se significaba en los posibles trayectos por cada pieza y del conjunto, concretando esta articulación de discursos, que va de un supuesto saber erudito a su reconversión para una incisiva lectura del contexto presente en sus vínculos con el pasado.

Musa Paradisíaca (1997/2017).

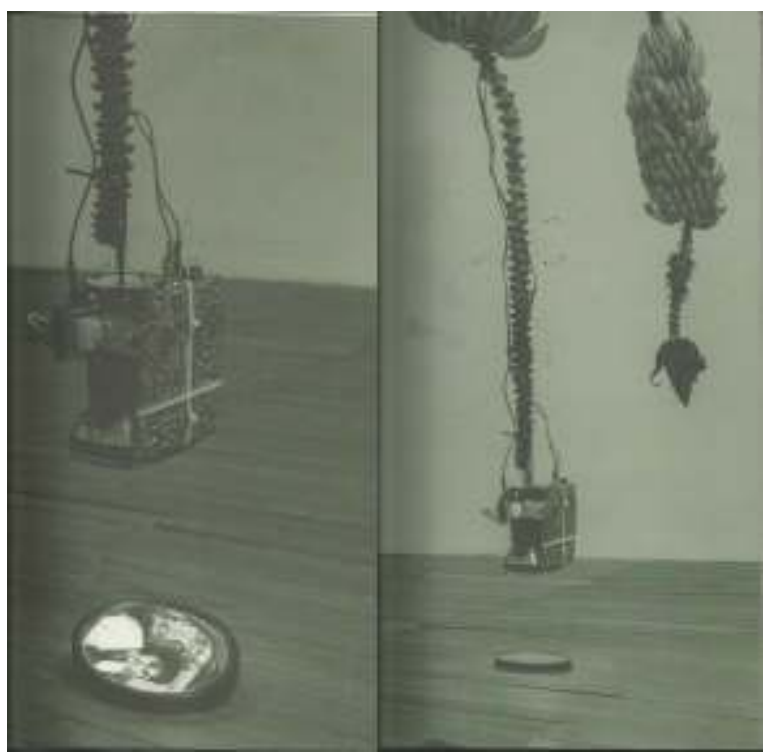

Colección de Arte del Banco de la República,

RESTREPO, JOSÉ ALEJANDRO

Entre la amplia serie de obras de una producción muy amplia, Musa paradisíaca $(1997 / 2014)^{10}$, es otra de las piezas que resume una práctica creativa pues concentra un proceso de pensamiento que es un modelo para armar según cada instalación. Este transcurso se origina en un grabado del siglo XIX de una mulata que yace frente a una planta de plátano hartón, de la denominación idílica del conjunto, de los frutos prohibidos a la dura historia de la producción de esta especie en la región de Urabá en el siglo XX. El grabado de Saffray deriva en las imágenes televisivas de las masacres provocadas por las empresas bananeras a lo largo del tiempo. Esta videoescultura, compuesta por racimos de plátano colgados con pequeños monitores de video con imágenes de los noticieros y de una pareja desnuda en el entorno de las plantaciones, resume un delicado proceso de relaciones y referencias, una sistemática en Restrepo ${ }^{11}$. El paraíso mítico se vincula al infierno presente como un montaje de representaciones que va del grabado al video. El espacio practicado implica emplazar un entorno natural, los bananos frescos, combinado con el espejismo de la luz de los monitores y el diseño del tiempo señalado por la duración de los videos al deterioro físico de las plantas. En sus diversos montajes ${ }^{12}$ a lo largo del tiempo va creciendo en su significación y propuesta estética, no solo por la actualidad política y la lectura del conflicto, sino también por su carácter visionario adelantado a la neocategoría de bioarte, ahora frecuente en el arte 
contemporáneo. Es de notar la manera en que los videos dejan su estadio individual monocanal y se transforman en una imagen constante bajo la forma del sinfín. Esta gramática de las cintas de video es parte de otra narrativa marcada por la sintaxis del loop y por su vecindad con las demás partes de cada instalación, el elenco de video monocanal es un archivo latente, paradigma que varía según cada obra y muestra. Por su parte, Musa Paradisíaca, inaugura una vertiente del bioarte, vinculada a la práctica de la instalación, para una obra compuesta por plantas de plátano, la cual sostiene sus frutos y los monitores de video por igual, y que en el transcurso del tiempo de la exposición se va deteriorando irremediablemente.

Es de referencia, la muestra Variaciones sobre el purgatorio (2011), que tuvo lugar en el Museo de la Universidad Nacional de Colombia, la cual se concentró en otro tema central para Restrepo como son los vínculos de la religiosidad cristiana en sus variadas representaciones a través de los tiempos ${ }^{13}$. Los grandes espacios en penumbras ofrecían grabados, fotografías, objetos e instalaciones; muestra antológica de la cual hay un detalle en el valioso catálogo ${ }^{14}$ y en el libro José Alejandro Restrepo ${ }^{15}$.

El discurso de inspiración religiosa se ampliaría en el evento Ejercicios Espirituales (2011) que tuvo lugar en La Casa del Teatro Nacional de Bogotá. Basado en el manifiesto homónimo de San Ignacio de Loyola, presentó un conjunto de acciones escénicas para un género único, cultivado por Restrepo desde la década de los ochenta, en el que el cuerpo es puesto en el centro de la escena como un rito de preparación religiosa para que el tiempo efímero de una obra eluda al objeto material coleccionable. La evocación a San Ignacio de Loyola recordaba personajes claves de la historia de las artes y los medios, entre ellos, el monje alemán Athanasius Kircher, por la investigación en la tecnologías de la imagen y el sonido en el Colegio de Jesús en Roma, durante el siglo XVII (Kircher, 2007). Estas referencias pueden remitirnos incluso a Joseph Beuys, cuando renueva su compromiso de vida con el arte luego de visitar simbólicamente Manresa, y cuando en su posterior acción de Dusseldorf asoció su crisis personal con el mismo enclave catalán donde Loyola concibió sus Ejercicios espirituales. Esta inspiración ignaciana se tradujo a una práctica escénica de los participantes en La Casa del Teatro Nacional a lo largo de cuatro semanas, siguiendo los tiempos propuestos por los ejercicios de Loyola. Las acciones improvisadas frente a inmensas proyecciones sobre la profundidad de campo fueron el fondo apropiado para las performances. Y nuevamente la imagen resultante de los archivos de video ${ }^{16}$ es proyectada sobre las paredes como fondo de los cuerpos de los actores. Una escena contemporánea que remite a Platón y Manresa, que contiene a un público ensimismado, en actitud devota, frente a las sombras, los cuerpos y las imágenes proyectadas. 
Invitación muestra: « José Alejandro Restrepo. Religión Catódica ».

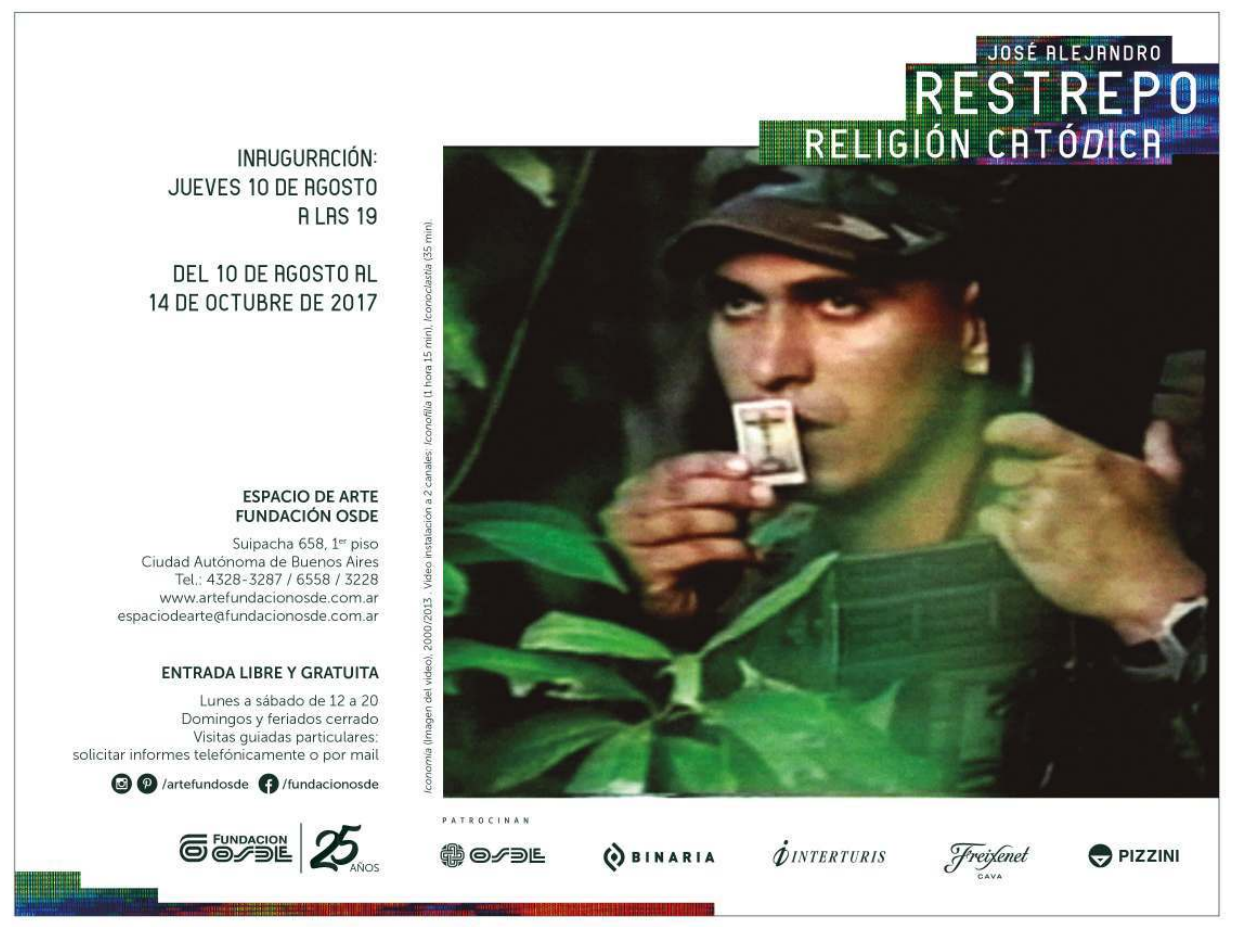

ESPACIO DE ARTE DE LA FUNDACIÓN OSDE, BUENOS AIRES, 2017

La tercera gran muestra personal que referenciamos es Religión Catódica (2017) presentada en Buenos Aires ${ }^{17}$ que puso en escena un amplio panorama de la obra de Restrepo a través basado en investigaciones sobre las elocuciones de los aparatos ideológicos formulados desde la arenga, la encíclica, el manifiesto y el bando militar. Esas invocaciones divinas, que promueven la evangelización del otro -es decir, el enemigo, el extraño, lo diferente, lo divergente-, las cuales eran desarmadas por Restrepo. La reminiscencia de imágenes del pasado y los textos de los medios masivos de comunicación funcionaron como una base de datos manifiesta mediante diversas formas y dispositivos. Las imágenes tecnológicas en cuestión procedían de un arte de la memoria y la crítica al poder dominante, expresado a través de la política, la religión y la educación desde las instituciones que lo sostienen. Asimismo, se destacaban las manifestaciones de un imaginario popular divergente de ese discurso dogmático. Una acción concentrada en la representación del cuerpo humano y la figura divina para una vertiente del arte contemporáneo en que el uso de la tecnología implicaba proponer formas expresivas desde el manejo del archivo. Así es como esta exposición surgía de una práctica artística que dialogaba asimismo con la imagen documental. En este sentido, la experimentación con la imagen de video operaba desde la apropiación del discurso de los medios, pero junto al rescate de expresiones espontáneas, alejadas del discurso establecido. José Alejandro Restrepo constituye el modelo virtuoso de autor contemporáneo que opera desde la hibridez de las tecnologías, quirográficas y maquínicas. Las imágenes pictóricas, fotográficas, electrónicas e informáticas se combinan con recurrencia en un preciso partido conceptual. 
Materiales para Misión en China (2017).

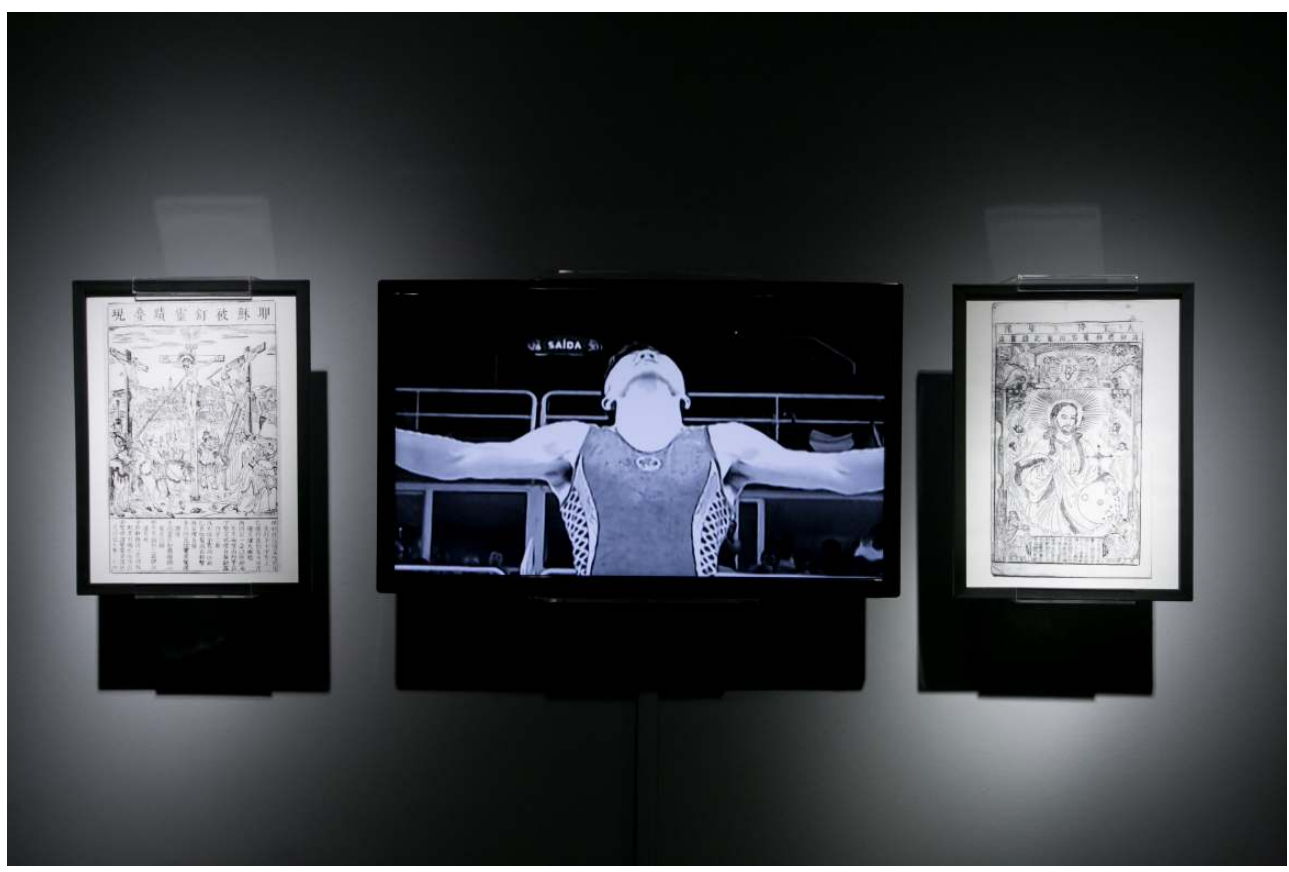

Montaje Religión Catódica, Buenos Aires 2017, Espacio de Arte de la Fundación OSDE.

FOTO ESTUDIO LEDESMA HUEYO

Un ejemplo relevante es una obra nueva, Materiales para Misión en China (2017) pensada para la exhibición de Buenos Aires, que presentaba un tríptico que compuesto de dos grabados y un video. Las históricas ilustraciones de Evangelicae Historiae Imagines (1537) de Jerónimo Nadal provienen de los grabados en la versión china de otro misionero jesuita, Giulio Aleni, (1637) publicada en Amberes. Relatos ejemplificadores que remiten a varias pistas históricas que Restrepo edita y pone en escena, refiriéndose a un tema central: la compleja instrucción religiosa instaurada por San Ignacio de Loyola desde la Compañía de Jesús. Los ejercicios espirituales de Loyola, Exercitia spiritualia (1522/1524), tendrían su fuente y correlato en sus escritos y derivaciones impresas. Por sugerencia de Loyola, el jesuita Nadal logra dibujos de una belleza inusual, que son reproducidos al presente, cuya inspiración resulta del método de concentración ignaciano. Es decir, la base de la meditación que propone Loyola sobre la vida de Jesús operaba en parte en la concentración en imágenes ópticas y mentales. El jesuita misionero, Giulio Alieni, iba a repensar una edición de los dibujos de Nadal adaptados para las misiones evangelizadoras en la China que tan bien conocía. Este es un tema mayor, pues se vincula con una historia de la representación, de textos e imágenes, que desarrolla la Iglesia a partir de la práctica religiosa de referencia instaurada por San Ignacio de Loyola, cuya influencia se mantiene durante siglos. Creer en Dios se deriva de la fe en los textos y las imágenes técnicas. Por su parte se retomaba la serie Variaciones sobre el Purgatorio. Así es como en su última versión de Buenos Aires (2017) Variación sobre El Purgatorio N.1 (2011) propuso un fondo cubierto por grabados. Este escenario empapelado con papel afiche de una misma imagen se complementaba con una proyección en video con la misma imagen, trabajada digitalmente, con variados efectos de luces y sombras que provocando un efecto alucinatorio. Una obra que se consuma con el espectador en la escena, observando. Este locus espacial y temporal nos remite a un limbo teatral, donde se combinan nuevamente 
las dos tramas preferidas de Restrepo, el grabado y la imagen de video, con el espectador completando la acción con su cuerpo y su mirada en una escena ominosa del purgatorio. Es el trabajo del artista Juan Cortés que asistió a Restrepo en todo el montaje técnico de Buenos Aires, para una instancia significativa, que sería una postproducción programada final de la proyección final de cada obra, específica para cada pieza ${ }^{18}$.

Variación sobre El Purgatorio N.1 (2011).

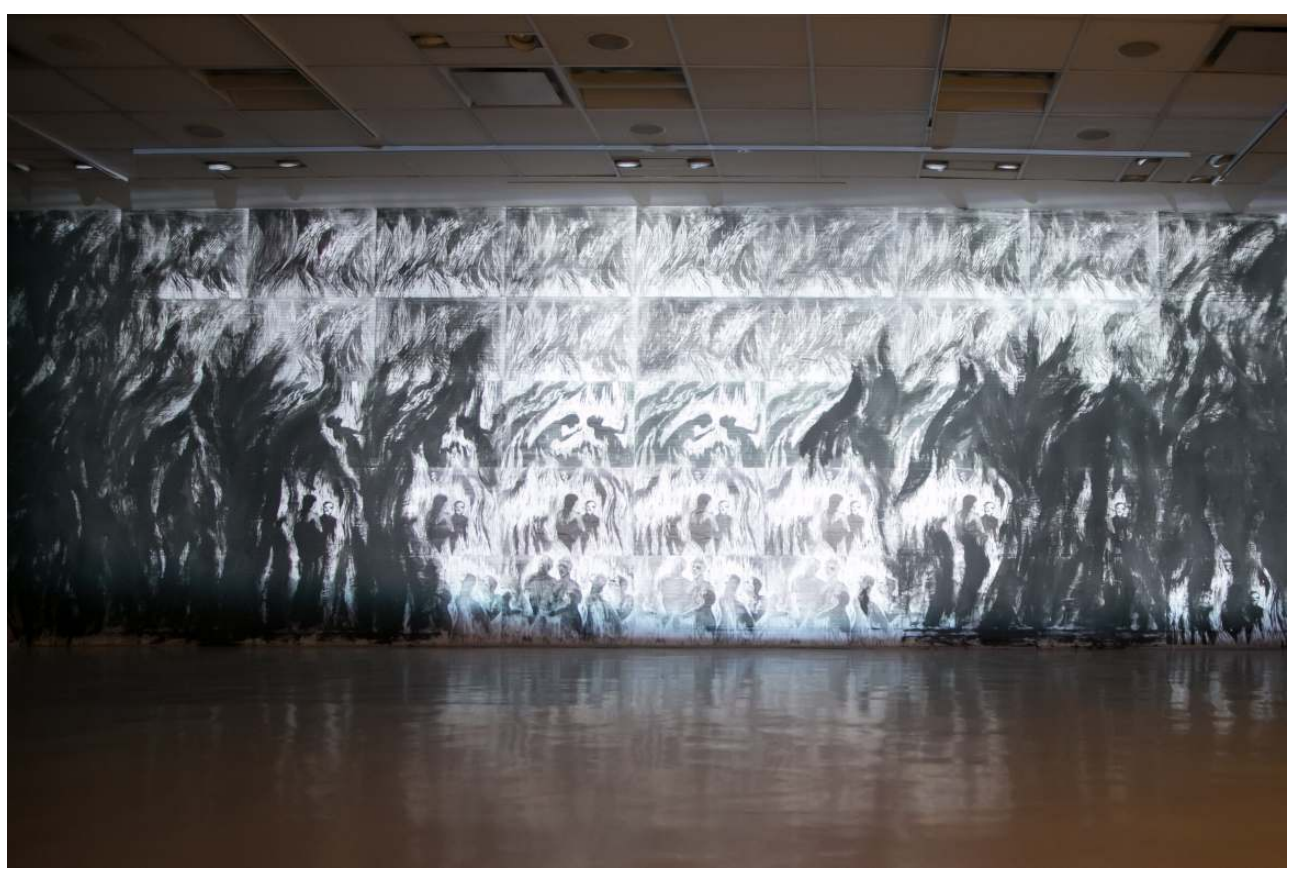

Montaje Religión Catódica, Buenos Aires 2017, Espacio de Arte de la Fundación OSDE.

FOTO ESTUDIO LEDESMA HUEYO

Por su parte la serie continuaba con Variación sobre El Purgatorio N.2 (2011) que es el paso intermedio que vincula el martirio contemporáneo con personajes del entorno escénico de una oficina. Cuerpos sin forma plena, al decir del Dante, cuerpos diluidos por la imagen de video, espectros en vida, muertos con permiso. ${ }^{19}$ Variación sobre el Purgatorio N.3 (2011) trata el martirio de los cuerpos purgando sus pecados en las llamas purificadoras. Una imagen ejemplificadora que se forma en la colisión de la proyección de video sobre la superficie de un vidrio templado que opera de pantalla que retiene pero también deja pasar la luz, como a la manera de un vitraux que contiene y refleja las imágenes sacras. Esta variable del dispositivo para la instalación, una pantalla en apariencia transparente, retoma otra idea de ícono religioso cercano al arte del fuego, en este caso para alcanzar otra vitrofusión de la imagen en movimiento del video incrustada en el vidrio. Es el volumen y la densidad de la pantalla colgada en el espacio lo que refuerza la idea de ventana iluminada por una imagen divina que proviene de las alturas. 
Video-Verónica (2000/2003).

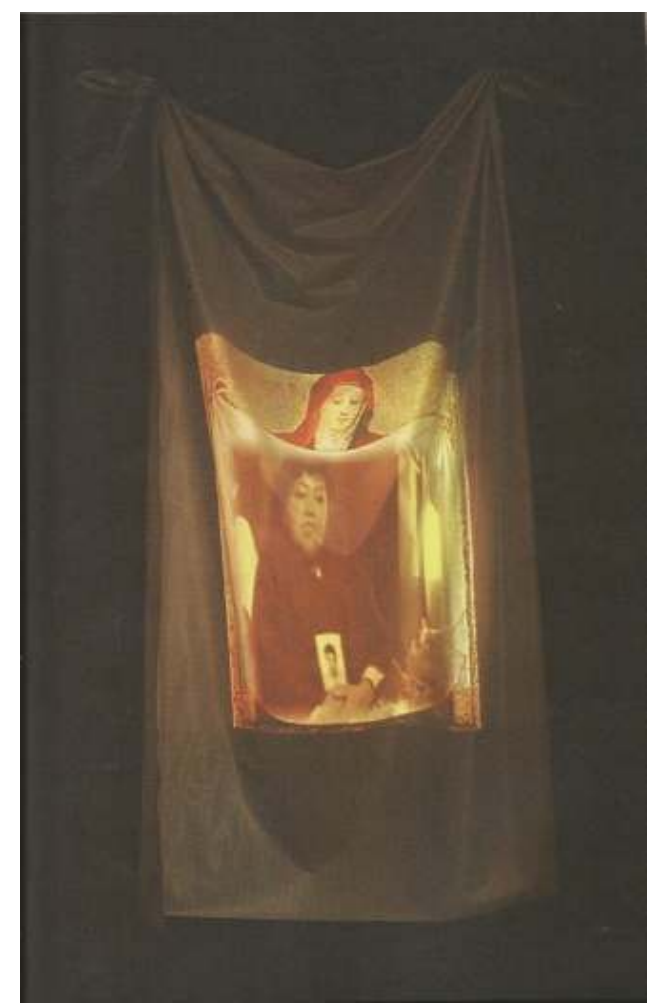

Montaje Religión Catódica, Buenos Aires 2017, Espacio de Arte de la Fundación OSDE. FOTO ESTUDIO LEDESMA HUEYO

13 La pieza Video-Verónica (2000/2003) tiene como pantalla una tela en la que se superpone la imagen del personaje bíblico, la acompañante del calvario con los retratos electrónicos de las madres contemporáneas. El dolor del rostro en la superficie del video tiene su punctum en la fotografía con el rostro del hijo martirizado. La iconografía cristiana con la invocación de la Santa Faz, o velo de Verónica, se cubre con el positivo fotográfico que rememora al que estuvo frente a cámara y ya no está. La fotografía retoma la función de aquellos lienzos sagrados y evoca lo que estuvo en cuerpo presente delante de la cámara. Un testimonio frente al paso del tiempo y la desaparición de lo viviente. La Vera Ícona, el Santo Sudario, son lienzos convertidos en imagen/pantalla. Otra estación de Religión catód ica en que el retrato tecnológico contemporáneo es ícono verdadero, lado anverso del paso de la muerte. 


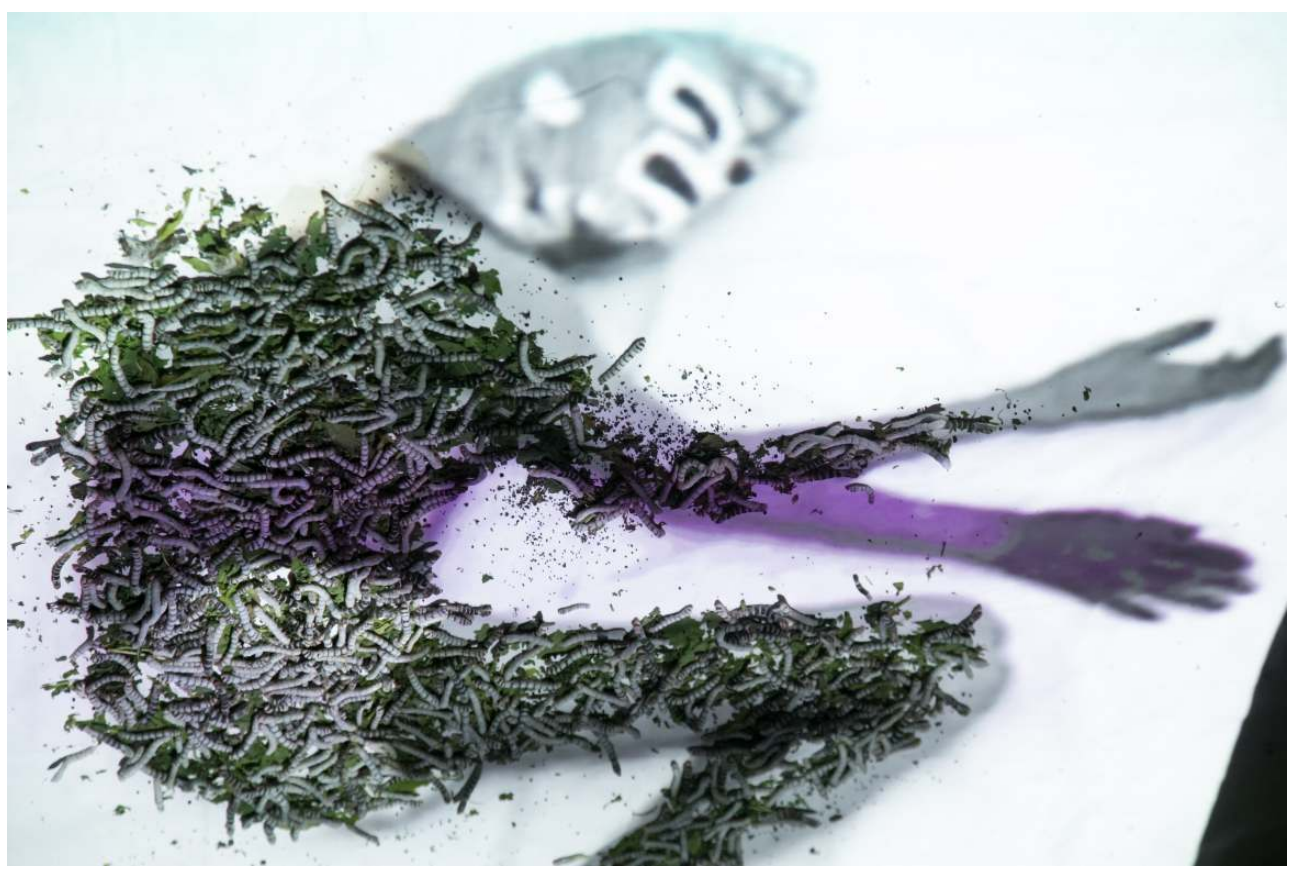

Montaje Religión Catódica, Buenos Aires 2017, Espacio de Arte de la Fundación ODE.

FOTO ESTUDIO LEDESMA HUEYO

En esta línea de pensamiento expositivo de la imagen en movimiento, Santo Job (2008) merece un capítulo especial al complejizarse el dispositivo y los elementos que componen la instalación. El haz de luz cenital, posible desde un proyector de corto alcance y su lente gran angular, se vuelve imagen en una sábana blanca que está sobre el piso. El esmirriado cuerpo del personaje que yace acostado contrasta con su máscara de El Santo, el héroe de la lucha libre mexicana. Pero en este Santo Job, la fragilidad del personaje inerte contrasta con la máscara del mediático y poderoso justiciero. Los gusanos de seda sobre la proyección del cuerpo se convierten en capullos y luego en mariposas. Santo Job se vincula con Musa Paradisíaca, pues como mencionado, se formula en la combinatoria de arte, tecnología, biología y naturaleza que suele denominarse bioarte. Aquel conjunto de plantas de banano, que se iban convirtiendo en detritus a lo largo de sus exhibiciones, tenía al final de su tronco una serie de pequeños monitores. El video, los pequeños tubos de rayos catódicos, la imagen electrónica, eran parte de una planta tropical tecnológica. Santo Job resume la fábula del personaje bíblico, Job, quien no duda de sus creencias, a pesar de la anunciada pérdida de sus hijos y de todos sus bienes. Las dudas sobre las causas de la inclusión del libro de Job como parte de los escritos bíblicos, así como de su misma existencia, se resumen en un relato ejemplificador sobre la fidelidad a Dios. El Santo Job contemporáneo de Restrepo resume vericuetos inspirados en otro relato que remite a escritos de Derrida o Benjamin ${ }^{20}$ tanto como al espectáculo de la lucha libre como programa televisivo. Las referencias a una cultura alta y a otra baja se combinan una vez más en Religión catódica. La materialidad de los elementos de la obra se concretiza en los diversos objetos y en su variada simbología: la sábana, el cuerpo y la máscara, los gusanos. Un conjuntoque toma forma en el espacio y el tiempo practicado -el suelo, la proyección cenital, los capullos como pantalla del cuerpo-y en el tiempo del video del proceso vital de los gusanos de seda. 
15 En Restrepo las piezas gráficas son un capítulo significativo dentro del conjunto de su obra $^{21}$. Rememoran a cronistas de la talla de Guamán Poma de Ayala, a los relevamientos de Humboldt, a partir de los diseños de Koch, y a los grabados de Duttenhofer. La referencia a La primera nueva crónica y buen gobierno (1615) de Ayala, el primer diseñador gráfico de América, dialoga por su originalidad con la producción editorial de Restrepo. La misma se aleja del rubro identificado con la difusión de una exposición, desde los folletos, hasta los afiches y el catálogo para un género anecdótico y referencial de una determinada muestra temporal. Pero en esta serie, el paso por la imprenta y el papel ponen de relieve una forma artística que merece un estudio particular por su amplitud y calidad, y que se presenta a través de piezas autónomas y de su relación con el resto de la obra de Restrepo. La temporalidad de las exhibiciones tiene un relevo en estos anarchivos ${ }^{22}$ a partir de vericuetos por escritos, fotografías, reproducciones, impresiones y sus múltiples combinatorias puestas en página que conforman un atlas relacional con el conjunto de la producción. La puesta en página, la diagramación, los formatos, las texturas, las tipografías, desde el diseño gráfico, se presentan como un relato con valor propio. De ahí toda la serie de piezas editoriales ${ }^{23}$ que sin duda vale la pena recopilar y que remite a un contexto de libro de artista en su reproductibilidad técnica.

El reconocimiento a la producción colombiana de artes visuales a través de premios, selecciones y menciones ha derivado en un generalizado optimismo considerando los variados lauros obtenidos en estos últimos tiempos ${ }^{24}$. El cine independiente y de autor, de ficción y no ficción, alcanza una merecida visibilidad a nivel nacional e internacional. Sin embargo, son pocas las obras y los artistas que consiguen articular un discurso coherente y profundo sobre lo que puede implicar el representar un país complejo y fascinante como Colombia. Tal vez sea en lo que respecta al cine, la forma y la duración del largometraje, que no termina de responder en su linealidad narrativa, literalidad expresiva y lenguaje clásico a un montaje complejo como puede ser el tratar la cuestión colombiana. Es la obra de Restrepo, como pocas, la que recoge una tradición de construcción y pensamiento a lo largo del tiempo, basado en serias investigaciones sobre la historia, los relatos del poder dominante y creencias populares que infieren una visión crítica en sus combinaciones e interpretaciones que desmantelan la ideología del sistema. La reminiscencia de textos e imágenes del pasado, los viajes por el país, la lectura y la deconstrucción de los mensajes de los medios masivos de comunicación funcionan como una base de datos y su procesamiento como sustento de cada obra. Restrepo continúa un relato conceptual que se inicia con el video y la imagen electrónica, el cual dialoga con vertientes del arte contemporáneo, en que los usos de la tecnología implican investigar otras formas expresivas y narrativas fuera de los grandes relatos del cine, la televisión, las redes de transmisión informáticas, el mercado del arte. Así se mantienen los principios de una práctica artística con las máquinas de imágenes donde surge un imaginario que es concepto a partir del desvío de los discursos del espectáculo y del mainstream del arte contemporáneo. 


\section{BIBLIOGRAFÍA}

BONET, Eugeni (2014), Escritos sobre vista y oído, Museo de Arte Contemporáneo de Barcelona, Barcelona.

LA FERLA, Jorge (2017), Religión Catódica, Catálogo de la exposición, Espacio de arte de la Fundación OSDE, Buenos Aires.

RESTREPO, J.A. Y SÁEZ DE IBARRA, M.B.(2011), Religión Catódica, Universidad Nacional de Colombia, Bogotá.

MARTÍN, Alejandro y ROCA, José (2016), José Alejandro Restrepo. Compendio, Colección de Arte Contemporáneo, Seguros Bolívar, Bogotá.

RESTREPO, José Alejandro (2016), Musa Paradisíaca, Fundación Flora, Bogotá.

II FESTIVAL FRANCOLATINO DE VIDEOARTE (1993), Embajada de Francia, Bogotá.

http://www.bibliotecanacional.gov.co/content/ii-festival-francolatinoamericano-devideoarte-1993

\section{NOTAS}

1. La vitalidad de la posición ideológica del video chileno durante la dictadura militar marcaba un camino desde la década de los ochenta tanto como el sólido desarrollo del video brasileño. Asimismo, se afirmaba el crecimiento del video argentino y del colombiano, los cuales encontraron un lugar de cruce en este festival organizado desde Europa, pero que tenía lugar en América Latina. En ese momento, las ediciones novena y décima de Videobrasil ya se concentraban en los países del hemisferio sur, de hecho, el Festival Franco Latinoamericano de Video Arte estuvo asociado durante varias ediciones con Videobrasil.

2. En aquel momento era el imperio de la cinta de media pulgada, el VHS y, en menor medida, el Betamax. Algunos privilegiados accedieron a soportes más sofisticados como el U Matic, el Betacam o el D1 de Sony. Restrepo siempre estuvo más allá de la diatriba sobre la calidad de los soportes.

3. Varios video artistas de aquella generación, como Andrés Di Tella (Argentina), Fabián Hofman (Argentina/México), Sandra Kogut (Brasil), Harold Trompetero (Colombia), por solo citar algunos, se han convertido en realizadores de largometrajes. Otros mantienen ambas actividades, como es el caso de María Paz Encina, Cao Guimaraes, Eder Santos.

4. Entre los legendarios autores que siguen en actividad, además de Restrepo, el brasileño Eder Santos, el argentino Carlos Trilnick por solo mencionar algunos de los más destacados de esa generación donde ocupaba un lugar destacado la mexicana Sarah Minter, recientemente decedida.

5. La selección de video colombiana no incluía la obra monocanal de Restrepo, quien como curador propuso la obra de otros realizadores, eludiendo otro hábito en los artistas que ofician de curadores.

6. Algunas de las referencias citadas en aquel texto fundacional eran la monodia del siglo XI, Enzesberger, García Canclini, J. Martín Barbero, publicidad de la cámara Sony, Nietzsche, James Juice (sic), Don Juan, Reichel-Domatoff, Jean-Paul Fargier, mitos indígenas Desama del Vaupés, 
Alfred Hitchcock, Bergson, los hopis, los kogi, entre otros, para un sistema riguroso de referencias.

7. Hacemos referencia a un posible proyecto a realizar considerando la propuesta del libro de Jean-Luc Godard Introducción a una verdadera historia del cine (1979), el cual ofrece, a partir de sus escritos y gráfica, una visión comparada de la historia del cine vinculada a su propios trayectos y que se continuaría con las Historia(s) del cine (1988/1998), aplicable en Restrepo.

8. BONET, E. (2014) Escritos sobre vista y oído, "Desmontaje documental" p.157 y "La apropiación es robo" p. 125

9. Anaconda (1993), Canto de Muerte (1999), Humboldt y Bonpland, taxidermistas (2001), Musa paradisíaca (1997), Ojo por diente (1994), Orestiada (1989), Paso del Quindío I (1989), Paso del Quindío II (1998).

10. RESTREPO, J.A. (2016) Musa Paradisíaca

11. Del grabado de Saffray Estudio de una planta de banano, Musa paradisíaca, siglo XIX, denominaciones de "Musa Sapientum" a "Amanita muscaria", Urabá y las plataneras, la guerra del banano y las masacres desde 1928; del mito del banano al conflicto político y económico moderno de su apropiación y comercio, situación que perdura hasta el momento actual a nivel internacional o local en la alianza terratenientes y paramilitares.

12. El último montaje de Musa paradisíaca que recorrí fue en la Casa Republicana de la Biblioteca Luis Ángel Arango en la muestra de nuevas adquisiciones "Evidencias de los hechos" (2014).

13. Instalaciones Variación sobre el purgatorio I, II, III, IV, V; Annus Mundi (2011); series:

“Bendición”, “Crucifijos”, "Mano de Dios”, “Misioneros”, serigrafías (2011).

14. RESTREPO, J.A. Y SÁEZ DE IBARRA, M.B.(2011), Religión Catódica.

15. MARTÍN, Alejandro y ROCA, José (2016), José Alejandro Restrepo. Compendio http://tangrama.co/ coleccion-de-arte-contemporaneo-seguros-bolivar-2/ Verificado el 15.9.2017

16. Ejercicios espirituales trabaja sobre versiones de los videos monocanales El Caballero de la Fe (2011), Estilita (2012), Iconomia (2009), Purgatorio (2011) y Verónica (2009).

17. http://www.artefundacionosde.com.ar/BO/muestra.asp?muestraId=1633 - 15.9.2017

18. Ver “Imágenes Catódicas Programadas", Juan Cortés en Religión Catódica (2017)

19. "Mi vista se enajena al ver adelantar esas visiones que personas no son de forma plena.", Dante Alighieri, Divina Comedia, citado en José Alejandro Restrepo, Religión Catódica (2011), ob. cit.

20. "Verme dormido", Bruno Mazzoldi en Jobs de Benjamin, Derrida y Restrepo. Bogotá, Valenzuela Klenner Galería, 2006.

21. Ver "Restrepo editor", Mariel Szlifman, en Religión Catódica (2017), ob. cit.

22. Según el término foucaultiano, aplicando el archivo como construcción subjetiva e interpretativa del pasado.

23. Cuerpo Gramatical. Cuerpo, arte y violencia (Universidad de los Andes, 2006); Dar la Cara I, II, III, IV (2013); Ejercicios espirituales (Universidad Nacional de Colombia, 2015); Hacer el sacrificio (Museo Nacional de Colombia, 2011); Vidas ejemplares (2008) y Video-Verónica (2009) implican una elaborada propuesta de diseño vinculada a las exposiciones y eventos, pero con valor propio con base en diversas maneras de concebir las artes gráficas.

24. Cámara de Oro en el Festival de Cannes (2015), país invitado en ARCO (2015), candidatura al Premio Óscar a mejor película extranjera (2016), primer premio del Festival Internacional de Cine de Cartagena (2016), entre otros. 


\section{RESÚMENES}

El artista colombiano José Alejandro Restrepo es una figura central del arte contemporáneo de América Latina. Desde hace treinta años su obra dialoga con la imagen documental a través de una obra exhibida bajo diversos formatos y dispositivos, focalizada en la crítica de las relaciones entre arte, historia, medios, religión y política. Modelo de artista contemporáneo que opera desde la hibridez de tecnologías ancestrales y modernas. El espacio de arte es el pórtico para explorar la noción de composición de lugar en la concentración a partir de las imágenes ópticas y mentales. El grabado, la fotografía, la imagen electrónica, la performance, el bioarte y el libro de artista sostienen la trama de un discurso cuyo desmontaje se emplaza en la práctica de la instalación.

L'artiste colombien José Alejandro Restrepo est une figure centrale de l'art latino-américain contemporain. Depuis trente ans, son travail propose des détours par rapport à l'image documentaire. Ses œuvres audiovisuelles sont exposées sous différents formats et dispositifs : vidéo, photographie, gravure, performance, bioart. Un travail anthologique axé sur la critique des relations entre l'art, l'histoire, les médias, la religion et la politique. Modèle d'artiste contemporain, le travail de Restrepo, fonctionne à partir de l'hybridation des technologies ancestrales, modernes et contemporaines. L'espace de l'art est la scène permettent d'explorer la notion d'histoire à partir de l'écriture avec les images optiques et mentales qui proposent un discours, dont son démantèlement est, situé dans la pratique de l'installation.

\section{ÍNDICE}

Mots-clés: vidéo art, installation, media, technologie, pouvoir, mémoire

Palabras claves: video arte, instalaciones, medios, tecnología, poder, memoria

\section{AUTOR}

\section{JORGE LA FERLA}

Jefe de Cátedra de la Universidad de Buenos Aires, Profesor de la Universidad del Cine.

Jorgelaferla(at)gmail.com 